Curr Diab Rep. 2018;18(10):72. doi: 10.1007/s11892-018-1042-0.

\section{Medicinal Plants with Multiple Effects on Diabetes Mellitus and Its Complications: A Systematic Review}

Zeinab Nazarian-Samani ${ }^{1}$, Robert D. E Sewell ${ }^{2}$, Zahra Lorigooini ${ }^{3}$, Mahmoud Rafieian-Kopaei ${ }^{3}$

${ }^{1}$ Basic Science Department, Veterinary Medicine Faculty, Shahrekord University, Shahrekord, Iran.

${ }^{2}$ Cardiff School of Pharmacy and Pharmaceutical Sciences, Cardiff University, Cardiff, CF10 3NB. Wales, U.K.

${ }^{3}$ Medical Plants Research Center, Basic Health Sciences Institute, Shahrekord University of Medical Sciences, Shahrekord, Iran.

\section{Corresponding author}

Mahmoud Rafieian-Kopaei

rafieian@yahoo.com

Tel: +989131811842 


\section{Abstract \\ Purpose of Review}

This systematic review describes evidence concerning medicinal plants that, in addition to exerting hypoglycemic effects, decrease accompanying complications such as nephropathy, neuropathy, retinopathy, hypertension and/or hyperlipidemia.

\section{Recent Findings}

Studies on the antidiabetic mechanisms of medicinal plants have shown that most of them produce hypoglycemic activity by: stimulating insulin secretion, augmenting peroxisome proliferator-activated receptors (PPARs), inhibiting $\alpha$-amylase or $\alpha$-glucosidase, inhibiting the secretion of glucagon-like peptide-1 (GLP-1), inhibiting advanced glycation end product (AGE) formation, free radical scavenging plus antioxidant activity (against reactive oxygenor nitrogen- species: ROS/RNS) up-regulating or elevating translocation of glucose transporter type 4 (GLUT-4) and preventing development of insulin resistance.

\section{Summary}

Not only are medicinal plants effective in diabetes mellitus, but many of them also possess a variety of effects on other disease states, including the complications of diabetes. Such plants may be appropriate alternatives or adjuncts to available antidiabetic medications.

\section{Keywords:}

Diabetes mellitus, Medicinal plants, Nephropathy, Neuropathy 


\section{INTRODUCTION}

Diabetes mellitus (DM) is one of the most common endocrine diseases worldwide, and the number of diabetics was recorded as 422 million in 2014. [1]. Type 1 DM is caused by impaired insulin secretion, while type $2 \mathrm{DM}$ is related to progressive insulin resistance in the liver and peripheral tissues, as well as relative insulin deficiency [2].

DM along with impaired glucose tolerance is a life-threatening illness that increases the risk of cardiovascular disease by as much as 8 times. The disease accounts for $60 \%$ of noninvasive amputations in the United States [3] and in 2015, 30.3 million Americans, were regarded to have DM, 7.2 million of which, were thought to be undiagnosed [4]. In the same year, an estimated 1.6 million deaths were directly attributed to diabetes and a further 2.2 million deaths were ascribed to high blood glucose [5]. It was also estimated that, by the year 2040, the number adult diabetics would increase to 642 million globally [6]. Higherthan-optimal blood glucose caused deaths, by increasing the risks of cardiovascular and other diseases. Forty-three percent of these deaths occurred before the age of 70 years [1].

Hyperglycemia causes an increase in oxidative stress, resulting in inflammation, activation of the polyol pathway, and damage to various organs of the body [7,8]. Diabetes requires diagnosis accompanied by medical management with lifestyle modification although currently, no successful causal treatment has been discovered. There are many synthetic drugs for the symptomatic treatment of $\mathrm{DM}$, but none of them are able to definitively alleviate the disease origin [9]. Common symptomatic treatments include regular injection of insulin or oral administration of antidiabetic drugs, such as sulfonylureas, $\alpha$-glucosidase inhibitors, biguanides, thiazolidinediones, dipeptidyl peptidase-4 (DPP4) inhibitors, sodiumglucose co-transporter-2 (SGLT2) inhibitors, glinides, and parenteral administration of 
glucagon-like peptide-1 (GLP-1) agonists, which can cause moderate to severe side effects [10]. As a result, alternative treatments are urgently needed for more effective management of the disease.

Complementary and alternative medicine (CAM) is increasingly being used as a diabetic management strategy. In this context, traditional herbal medicine is used across the world for disease treatment [11]. The World Health Organization has recommended that clinicians use herbal drugs to treat DM in addition to its complications. There is no ultimate method available to prevent and treat DM, but strategies are needed to reduce the complications brought about by the disease $[12,13]$. Some medicinal plants with antioxidant properties are useful for reducing oxidative stress and its adverse effects [14, 15] and nowadays, some of the available drugs are plant-based [16]. Research has shown that a number of antidiabetic plants, apart from their hypoglycemic activity, have other useful properties such as antihypertensive, nephroprotective and retinoprotective activities which may be useful against the most common complications of DM. Thus, consumption of these plants may well be exploited in the control of DM and its complications [17, 18]. Hence, the purpose of this article is to systematically review the medicinal plants that are useful in the management of DM and its accompanying complications.

\section{MATERIALS AND METHODS}

To conduct this review, firstly the complications caused by DM were addressed. Subsequently, underlying antidiabetic mechanisms of medicinal plants were reviewed under general thematic headings. For this purpose, the articles indexed in PubMed, Scopus, Web of Science, MEDLINE, Google Scholar, Web of Science (SCOPUS), EBSCO Academic Search, 
Cochrane Central Register of Controlled Trials (CENTRAL), and the Chinese Network Knowledge Infrastructure (CNKI) and published prior to 2018 were retrieved using the keywords "hypertension", "retinopathy", "neuropathy", and "nephropathy" or "medical plants for diabetic hypertension or retinopathy or nephropathy or neuropathy" were reviewed. Articles containing plants affecting one or more of the above items were selected. A total of 36,000 publications were retrieved by the first selection process. Out of these publications, 305 articles identified in which medical plants were examined against DM and/or diabetic complications (hypertension, retinopathy, nephropathy, neuropathy and/or hyperlipidemia). After a more detailed review of these articles, 89 relevant papers were selected and their applicable findings summarized in tabular form.

\section{RESULTS}

\section{Medicinal herbs effective on diabetes:}

The use of antioxidants and the reduction and control of blood glucose significantly reduce the complications associated with DM $[19,20]$. Consequently, medicinal plants with antioxidant properties are employed to restrict oxidative stress and its adverse effects [21, 22]. A number of medicinal plants with antidiabetic and antihyperlipidemic effects are known to be effective in preventing and treating DM.

\section{Antidiabetic plant mechanisms}

There are several fundamental modes of action for natural products in DM [23]. The principal mechanisms include those that act by: stimulating insulin secretion, augmenting peroxisome proliferator-activated receptors (PPARs), inhibiting $\alpha$-amylase or $\alpha$-glucosidase, 
inhibiting the secretion of the incretin, glucagon-like peptide-1 (GLP-1), inhibiting advanced glycation end product (AGE) formation, free radical scavenging plus antioxidant activity (against reactive oxygen- or nitrogen- species: ROS/RNS) up-regulating or elevating translocation of glucose transporter type 4 (GLUT-4) and preventing development of insulin resistance (Figure 1).

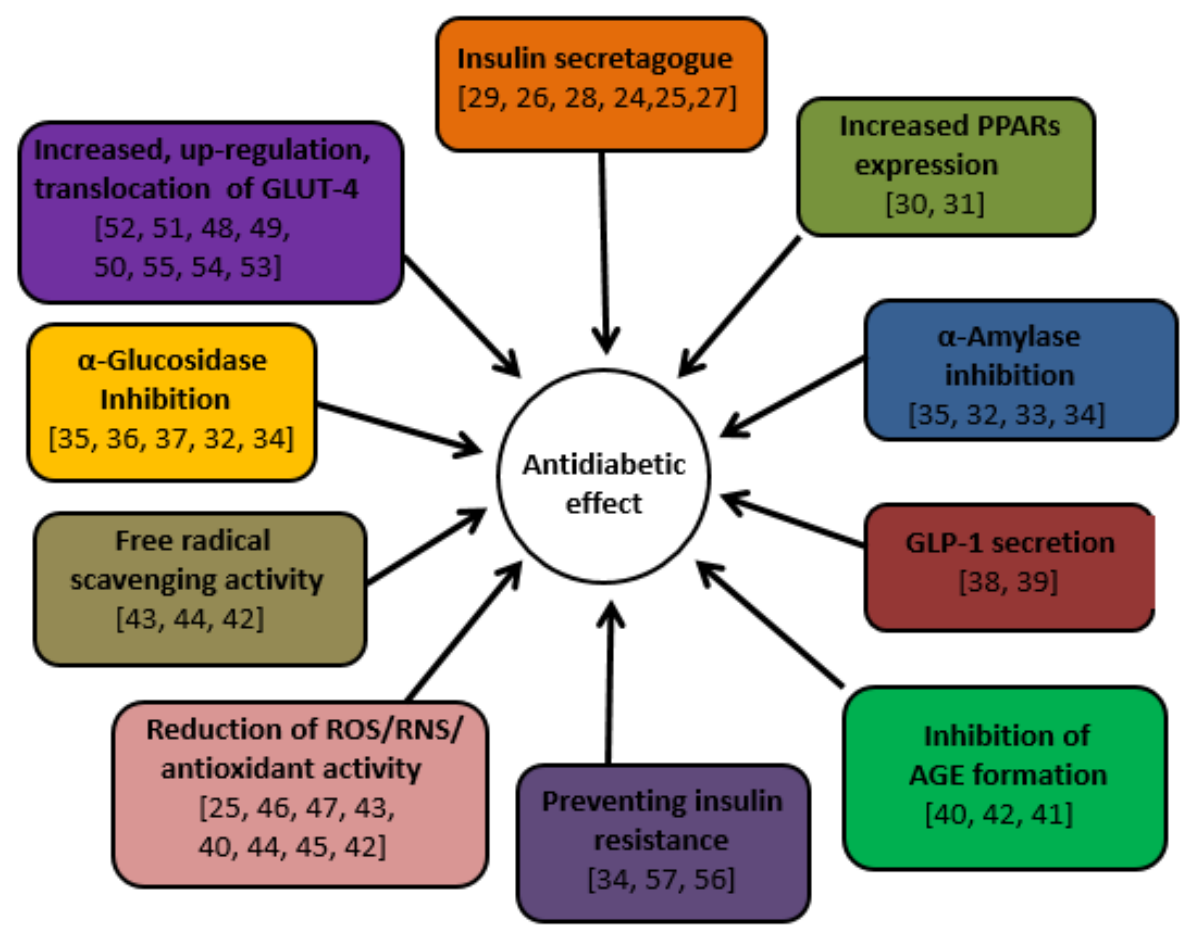

Figure 1. Diagram depicting some of the principle plant-derived mechanisms of antidiabetic activity.

GLUT-4 = Insulin-regulated glucose transporter type 4; ROS = Reactive oxygen species;

RNS = Reactive nitrogen species; AGE = Advanced glycation end products;

DPP4 = Dipeptidyl peptidase; GLP-1 = Glucagon-like peptide-1 (incretin);

PPARs = Peroxisome proliferator-activated receptors 


\section{Insulin secretagogues}

Some plants or their constituents stimulate insulin secretion. They include: Panax ginseng [24] and the diosgenin component in Fenugreek (Trigonella foenum graecum) [25, 26, 27] which also increases glucose metabolism not only by stimulating adipocyte differentiation but also via a reduction of inflammation in adipocytes [28]. There is in addition, an insulin secretagogic action of the compound S-methyl cysteine sulfoxide which has been isolated from the onion plant (Allium cepa) [29].

\section{Increased expression of peroxisome proliferator-activated receptors (PPARs)}

In bitter melon (Momordica charantia L.), 9cis, 11trans, 13trans-conjugated linolenic has been found to activate PPARalpha in rat tissues [30]. In addition, momordin extracted from bitter melon, increases the expression of human PPARdelta mRNA and the production and activation of PPARdelta is further upregulated through PPARdelta promoter activity [31].

\section{$\alpha$-Amylase and $\alpha$-glucosidase inhibition}

Azadirachtolide, isolated from Azadirachta indica (also known as Neem tree) has been shown to exhibit anti-hyperglycaemic and anti-lipidemic actions in diabetic rats. Furthermore, an inhibitory activity of azadirachtolide on $\alpha$-amylase and $\alpha$-glucosidase has been demonstrated, suggesting that this $A$. indica constituent is potentially beneficial in the management of diabetes associated with an abnormal lipid profile coupled with related cardiovascular complications [32]. Moreover, the limonoids azadiradione and gedunin plus the tetranortriterpenoid compound meliacinolin isolated from A. indica, are also inhibitory on both $\alpha$-amylase and $\alpha$-glucosidase further indicating that this medicinal plant has a propensity to reduce post-prandial hyperglycemia in the diabetic condition [33, 34]. 
Additionally, extracts from cinnamon bark species possess inhibitory activity against intestinal $\alpha$-glucosidase and pancreatic $\alpha$-amylase [35] and even after chronic extract administration, $\alpha$-glucosidase activity remains at a low level, so this natural product has promise in DM [36]. What is more, an extract of onion (A. cepa) containing the phenolic compound quercetin, also possesses $\alpha$-glucosidase inhibitory activity [37].

\section{Increased glucagon-like peptide-1 (GLP-1) secretion}

It has been demonstrated in vitro and in vivo that the saponin ginsenosides present in $P$. ginseng stimulate GLP-1 secretion and this incretin reduces hyperglycemia significantly contributing towards an antidiabetic effect [38]. Apart from $P$. ginseng, other medicinal plants including Anemarrhena asphodeloides, Citrus aurantium, Bupleurum falcatum and Gentiana scabra also have GLP-1 secretogogic activity [39].

\section{Inhibition of advanced glycation end-product (AGE) formation}

Advanced glycation end-products (AGEs) cause inflammation and have a crucial role in generating diabetic complications. In light of this, catalpol isolated from Rehmannia glutinosa restrains AGE-mediated inflammation by inhibiting ROS production and NADPHoxidase activity and this is considered to prevent AGE-mediated problems in DM [40]. An extract from A. indica also inhibits AGE formation in addition to oxidative stress and it is thought to have a protective effect in diabetic kidney disease [41]. Similarly, a Piper auritum leaf extract has been reported to have concomitant antioxidant as well as AGE inhibitory activities [42]. 


\section{Free radical scavenging activity}

An extract from $R$. glutinosa rhizome displayed free radical scavenging activity reducing the level of ROS intracellularly in addition to diminishing pro-inflammatory gene expression and this finding, has been advocated as a therapeutic possibility for DM [43]. Likewise, $T$. foenum graecum (Fenugreek) seeds boost antioxidant status in the blood suggesting that perturbed free radical metabolism in the diabetic condition may be returned to normal [44]. It is of note in this regard, that a range of other plants used to treat diabetes, exhibit activity in the DPPH (2, 2-Diphenyl-1-picrylhydrazyl) test for free radical scavengers [42].

\section{Reduction of antioxidant/ROS/RNS activity}

Invariably, studies on free radical scavengers are performed in the context of antioxidant activity. Thus, $R$. glutinosa has strong free radical scavenging effects which are coincident with a reduced production of ROS [43] and this is attributable to catalpol [40]. Fenugreek increases lipid peroxidation and blood antioxidants in diabetic rats [44] and its constituent trigonelline, acts by affecting ROS [25] while the steroidal saponin, diosgenin, also present in yam (Dioscoreaceae family), modulates oxidative stress [45]. The ginsenoside-Rg1 component of $P$. ginseng improves angiogenesis in diabetic ischemic rat hindlimb which is believed to be through increased activation of endothelial nitric oxide synthase (eNOS) [46]. Another $P$. ginseng constituent, 20(S)-ginsenoside $\operatorname{Rg}(3)$, produces positive effects on diabetic renal damage which have been assigned to inhibition of NMDA receptor-mediated nitrosative stress [47]. It is also noteworthy that there are other examples of antidiabetic plant-induced antioxidant activity [42]. 


\section{Increased, up-regulation and translocation of glucose transporter type 4 (GLUT-4)}

Glut-4 is one of the most important insulin regulated glucose transporters located at the surface membrane of adipocytes, skeletal and cardiac muscle cells. A triterpenoid constituent of $M$. charantia fruit, cucurbitane [48], stimulates GLUT-4 cell membrane translocation to facilitate glucose uptake and AMP-activated protein kinase (AMPK) phosphorylation [4951]. A comparable effect occurs with an extract of $A$. cepa [52]. Likewise, in mouse adipocytes, an aqueous extract of Cinnamon evokes a biphasic action on GLUT-4 mRNA [53] whereas an active constituent of the plant, cinnamaldehyde, increases glucose uptake through augmented GLUT4 translocation [54]. Ginsenoside-Rh2 present in P. ginseng decreases plasma glucose in diabetic rats by increasing GLUT-4 expression via a more indirect mechanism arising from elevated $\beta$-endorphin stimulation of $\mu$-opioid receptors [55].

\section{Insulin resistance reduction}

Insulin resistance (IR) is a pathological condition in which cells do not respond normally to insulin. In this respect, Ocimum sanctum (Holy basil) delays the onset of insulin resistance in rats and has been proposed as an adjuvant therapy for patients who develop this condition [56]. Also, in rats, meliacinolin isolated from the leaves of $A$. indica inhibits insulin resistance among a number of other antidiabetic modes of action [34]. Analogously, $M$.

Charantia ameliorates insulin resistance in mice though the underlying mechanism has been hypothesized to be through PPARgamma-mediated pathways [57].

There are over 400 plant species with hypoglycemic properties. However, the study of new antidiabetic, plant-derived drugs is still pursued and continues to draw attention because of 
potential safety issues. Most of the plants contain alkaloids, glycosides, terpenoids, flavonoids and carotenoids, to which their antidiabetic properties have been attributed. Several medicinal plants such as Galega officinalis, in addition to producing positive effects on glucose homeostasis in diabetic patients, have found application in preventing and treating hypertension, cardiovascular disease, and kidney injury $[13,58,59,60]$. In addition to producing hypoglycemic effects, numerous plants have been demonstrated to be effective against the wide range of diabetic complications (Table 1). In Table 2, the mechanisms of the effects of these plants are summarized.

\section{CONCLUSION:}

Problems arising from insulin resistance and chronic hyperglycemia have become a major concern in clinical science and drug therapy. Medicinal plants have usually attracted attention conceivably due to fewer side effects than chemically synthetic drugs. The antihyperglycemic effects of the plants presented in this article are essentially related to their ability to maintain pancreatic function and insulin output facilitating anabolic activities such as muscle, adipocyte and hepatic glucose uptake as well as glucose-to-glycogen conversion.

Oxidative stress induced by hyperglycemia plays an important role in the expansion of the extracellular matrix and glucose-induced collagen production [206]. When endothelial cells respond to increased glucose, the production of reactive nitrogen species and ROS increases. The production of these reactive substances triggers single-strand breakage of DNA, and subsequently increases the levels of 8-hydroxyguanine and 8-hydroxydeoxy guanosine (markers of oxidative stress-induced DNA damage) in plasma and tissues. The 
concentrations of these products can be restrained by controlling hyperglycemia and using antioxidants [207]. Studies have shown that the use of antioxidants has been successful in preventing DM-induced disorders, including neuropathy, nephropathy and retinopathy. High doses of single antioxidants, such as vitamin $\mathrm{E}$ or vitamin $\mathrm{C}$, may interfere with the antioxidant-provident balance in the cellular system, so it has been suggested that a mixture of therapeutic antioxidants with trace elements and vitamins may be used to improve the metabolic system [208]. More importantly, single antioxidants may not be able to counteract all free radical species; hence, medicinal plants which possess a wide range of phytochemicals with antioxidant activities may be more efficient.

Although treatment with medicinal plants has significant effects on pancreatic $\beta$-cells reducing blood glucose levels as well as other DM-related complications, there is scant information on their biology, especially how they actually affect DM. However, it has been shown that most medicinal plants contain compounds such as glycosides, alkaloids, terpenoids, and flavonoids, which mitigate DM by exerting antioxidant effects and other related activities [71-73]. Taken together, although plants may have antidiabetic effects with their own specific action mechanism, almost all of them display antioxidant properties and a range of other contributory actions. Given that oxidative stress is one of the main causes of DM and its related disorders, it is likely that the antioxidant effect of these plants plays a major role in their effectiveness.

Finally, it can be concluded that medicinal plants that produce a profile of concomitant effects may be considered as alternative or adjunctive drugs for the treatment or prevention of DM and its complications. It is however, essential to study the effects of medicinal plants 
on DM in more detail in order to obtain further data on the biology and pharmacological effects of these plants.

\section{Conflict of Interest}

Zeinab Nazarian-Samani, Robert D. E Sewell, Zahra Lorigooini, and Mahmoud RafieianKopae declare that they have no conflict of interest.

\section{Human and Animal Rights and Informed Consent}

This article does not contain any studies with human or animal subjects performed by any of the authors.

\section{REFERENCES:}

Papers of particular interest, published recently, have been highlighted as:

•* Of importance

** Of major importance

1. Global report on diabetes: World Health Organization. ISBN 9789241565257 (NLM classification: WK 810)

2. Mahmoudian-Sani MR, Luther T, Asadi-Samani M, et al. A new approach for treatment of type 1 diabetes: Phytotherapy and phytopharmacology of regulatory T cells. J Renal Inj Prev 2017; 6(3):158-63.

3. Norhammar A, Tenerz A, Nilsson G, et al. Glucose metabolism in patients with acute myocardial infarction and no previous diagnosis of diabetes mellitus: a prospective study. Lancet 2002;359(9324):2140-44. 
4. American Diabetic Association (2018) http://www.diabetes.org/diabetes-basics/statistics/ (accessed 29 $9^{\text {th }}$ June 2018)

5. WHO fact sheet detail 2017. http://www.who.int/news-room/fact-sheets/detail/diabetes (accessed 29th June 2018)

6. Herman WH. The Global Burden of Diabetes: An Overview. In: Dagogo-Jack S. (eds) Diabetes Mellitus in Developing Countries and Underserved Communities. 2017 pp 1-5 Springer, Cham ISBN 978-3-319-41557-4

7. Amiri M. Oxidative stress and free radicals in liver and kidney diseases; an updated shortreview. J Nephropathol 2018; 7(3):127-31.

8. Rahimpour S, Hasanpour Dehkordi A. Antioxidant defense system versus 8-hydroxy-2' deoxyguanosine; a short look to recent findings. J Renal Inj Prev 2018; 7(3):121-23.

9. Li WL, Zheng HC, Bukuru J, et al. Natural medicines used in traditional Chinese medical system for therapy of diabetic mellitus. J Ethnopharmacol. 2004; 92: 1-21.

10. Gourgari E, Wilhem EE, Hassanzadeh H, et al. A comprehensive review of the FDAapproved labels of diabetes drugs: Indications, safety, and emerging cardiovascular safety data. J Diabetes Comp 2017;31:1719-27.

11. Gardner DG, Shoback D. Greenspan's basic \& clinical endocrinology. $9^{\text {th }}$ ed. New York: McGraw-Hill Medical 2013;7-14.

12. Amiri M. Type 2 diabetes mellitus; an international challenge. Ann Res Dial 2016; 1(1): $\mathrm{e} 04$. 
13. Tavafi M. Diabetic nephropathy and antioxidants. J Nephropathol 2013; 2(1): 20-27.

14. Baradaran A. The role of biomarkers to detect progression of diseases. J Negat Results Clin Exp Stud 2018; 1(1): e05.

15. Hajian S. Positive effect of antioxidants on immune system. Immunopathol Persa 2015; 1(1): e02.

16. Fabricant DS, Farnsworth NR. The value of plants used in traditional medicine for drug discovery. Environ Health Perspect 2001; 109(1): 69-75.

17. World Health Organisation. Definition and diagnosis of diabetes mellitus and intermediate hyperglycaemia [internet]. 2006. Available from: http://www.who.int/diabetes/publications/diagnosis_diabetes2006/en/.

18. Aghadavoud E, Nasri H, Amiri M. Molecular signaling pathways of diabetic kidney disease; new concepts. J Prev Epidemiol 2017; 2(2): e03.

19. Amiri M. Type 2 diabetes mellitus; an international challenge. Ann Res Dial 2016; 1(1): $\mathrm{e} 04$.

20. Tavafi M. Diabetic nephropathy and antioxidants. J Nephropathol 2013; 2(1): 20-27.

21. Baradaran A. The role of biomarkers to detect progression of diseases. J Negat Results Clin Exp Stud 2018; 1(1): e05.

22. Nasri H, Shirzad H. Toxicity and safety of medicinal plants. J Herbmed Plarmacol 2013; 2(2): 21-22. 
23. • Governa, P, Baini, G, Borgonetti, V, Cettolin, G, Giachetti, D, Magnano, AR, Miraldi, E, Biagi, M. Phytotherapy in the management of diabetes: a review. Molecules. 2018 4;23(1): pii: E105.

24. Ota, A.; Ulrih, N.P. An overview of herbal products and secondary metabolites used for management of type two diabetes. Front. Pharmacol. 2017, 8, 1-14.

25. Zhou, J.; Chan, L.; Zhou, S. Trigonelline: A plant alkaloid with therapeutic potential for diabetes and central nervous system disease. Curr. Med. Chem. 2012, 19, 3523-3531.

26. Kalailingam, P.; Kannaian, B.; Tamilmani, E.; Kaliaperumal, R. Efficacy of natural diosgenin on cardiovascular risk, insulin secretion, and beta cells in streptozotocin (STZ)induced diabetic rats. Phytomedicine 2014, 21, 1154-1161.

27. Broca, C.; Manteghetti, M.; Gross, R.; Baissac, Y.; Jacob, M.; Petit, P.; Sauvaire, Y.; Ribes, G. 4-Hydroxyisoleucine: Effects of synthetic and natural analogues on insulin secretion. Eur. J. Pharmacol. 2000, 390, 339-345.

28. Uemura, T, Hirai, S, Mizoguchi, N, Goto, T, Lee, J.Y, Taketani, K.; Nakano, Y.; Shono, J.; Hoshino, S.; Tsuge, N.; et al. Diosgenin present in fenugreek improves glucose metabolism by promoting adipocyte differentiation and inhibiting inflammation in adipose tissues. Mol. Nutr. Food Res. 2010, 54, 1596-1608.

29. Kumari, K.; Augusti, K.T. Antidiabetic and antioxidant effects of S-methyl cysteine sulfoxide isolated from onions (Allium cepa Linn) as compared to standard drugs in alloxan diabetic rats. Indian J. Exp. Biol. 2002, 40, 1005-1009. 
30. Chuang, C.-Y.; Hsu, C.; Chao, C.-Y.; Wein, Y.-S.; Kuo, Y.-H.; Huang, C. Fractionation and identification of 9c, 11t, 13t-conjugated linolenic acid as an activator of PPARalpha in bitter gourd (Momordica charantia L.). J. Biomed. Sci. 2006, 13, 763-772.

31. Sasa, M.; Inoue, I.; Shinoda, Y.; Takahashi, S.; Seo, M.; Komoda, T.; Awata, T.; Katayama, S. Activating effect of momordin, extract of bitter melon (Momordica Charantia L.), on the promoter of human PPARdelta. J. Atheroscler. Thromb. 2009, 16, 888-892.

32. Kumar, D.B.; Mitra, A.; Manjunatha, M. Azadirachtolide: Pharmacogn. Commun. 2011, 1, 78-84.

33. Ponnusamy, S.; Haldar, S.; Mulani, F.; Zinjarde, S.; Thulasiram, H.; RaviKumar, A. Gedunin and Azadiradione: Human Pancreatic Alpha-Amylase Inhibiting Limonoids from Neem (Azadirachta indica) as Anti-Diabetic Agents. PLoS ONE 2015, 10, e0140113.

34. Perez-Gutierrez, R.M.; Damian-Guzman, M. Meliacinolin: A potent alpha-glucosidase and alpha-amylase inhibitor isolated from Azadirachta indica leaves and in vivo antidiabetic property in streptozotocin-nicotinamide-induced type 2 diabetes in mice. Biol. Pharm. Bull. $2012,35,1516-1524$.

35. Adisakwattana, S.; Lerdsuwankij, O.; Poputtachai, U.; Minipun, A.; Suparpprom, C. Inhibitory activity of cinnamon bark species and their combination effect with acarbose against intestinal alpha-glucosidase and pancreatic alpha-amylase. Plant Foods Hum. Nutr. 2011, 66, 143-148.

36. Kim, S.H.; Hyun, S.H.; Choung, S.Y. Anti-diabetic effect of cinnamon extract on blood glucose in db/db mice. J. Ethnopharmacol. 2006, 104, 119-123. 
37. Kim, S.-H.; Jo, S.-H.; Kwon, Y.-I.; Hwang, J.-K. Effects of Onion (Allium cepa L.) Extract Administration on Intestinal $\alpha$-Glucosidases Activities and Spikes in Postprandial Blood Glucose Levels in SD Rats Model. Int. J. Mol. Sci. 2011, 12, 3757-3769.

38. Liu, C.; Zhang, M.; Hu, M.-Y.; Guo, H.-F.; Li, J.; Yu, Y.-L.; Jin, S.; Wang, X.-T.; Liu, L.; Liu, X.-D. Increased glucagon-like peptide-1 secretion may be involved in antidiabetic effects of ginsenosides. J. Endocrinol. 2013, 217, 185-196.

39. Kim K S, Jang H J. Medicinal plants Qua Glucagon-Like Peptide-1 Secretagogue via Intestinal Nutrient Sensors. Evid Based Complement Alternat Med. 2015;2015:171742. doi: $10.1155 / 2015 / 171742$.

40. Choi, H.-J.; Jang, H.-J.; Chung, T.-W.; Jeong, S.-I.; Cha, J.; Choi, J.-Y.; Han, C.W.; Jang, Y.-S.; Joo, M.; Jeong, H.-S.; et al. Catalpol suppresses advanced glycation endproducts-induced inflammatory responses through inhibition of reactive oxygen species in human monocytic THP-1 cells. Fitoterapia 2013, 86, 19-28.

41. Perez Gutierrez RM, de Jesus Martinez Ortiz M. Beneficial effect of Azadirachta indica on advanced glycation end-product in streptozotocin-diabetic rat. Pharm Biol. 2014 Nov;52(11):1435-44. doi: 10.3109/13880209.2014.895389. Epub 2014 Jul 15.

42. Dzib-Guerra W D, Escalante-Erosa F, García-Sosa K, Derbré S, Blanchard P, Richomme P, Peña-Rodríguez L M. Anti-advanced glycation end-product and free radical scavenging activity of plants from the Yucatecan flora. Pharmacognosy Res. 2016;8(4):276-280. 
43. Baek, G.-H.; Jang, Y.-S.; Jeong, S.-I.; Cha, J.; Joo, M.; Shin, S.-W.; Ha, K.-T.; Jeong, H.-S. Rehmannia glutinosa suppresses inflammatory responses elicited by advanced glycation end products. Inflammation 2012, 35, 1232-1241.

44. Ravikumar, P.; Anuradha, C.V. Effect of fenugreek seeds on blood lipid peroxidation and antioxidants in diabetic rats. Phytother. Res. 1999, 13, 197-201.

45. Son, I.S.; Kim, J.H.; Sohn, H.Y.; Son, K.H.; Kim, J.-S.; Kwon, C.-S. Antioxidative and hypolipidemic effects of diosgenin, a steroidal saponin of yam (Dioscorea spp.), on highcholesterol fed rats. Biosci. Biotechnol. Biochem. 2007, 71, 3063-3071.

46. Yang, N.; Chen, P.; Tao, Z.; Zhou, N.; Gong, X.; Xu, Z.; Zhang, M.; Zhang, D.; Chen, B.; Tao, Z.; Yang Z. Beneficial effects of ginsenoside-Rg1 on ischemia-induced angiogenesis in diabetic mice. Acta Biochim. Biophys. Sin. 2012, 44, 999-1005.

47. Kang, K.S.; Yamabe, N.; Kim, H.Y.; Park, J.H.; Yokozawa, T. Therapeutic potential of 20(S)-ginsenoside $\operatorname{Rg}(3)$ against streptozotocin-induced diabetic renal damage in rats. Eur. J. Pharmacol. 2008, 591, 266-272.

48. Ma, J.; Whittaker, P.; Keller, A.C.; Mazzola, E.P.; Pawar, R.S.; White, K.D.; Callahan, J.H.; Kennelly, E.J.; Krynitsky, A.J.; Rader, J.I. Cucurbitane-type triterpenoids from. Planta Med. 2010, 76, 1758-1761.

49. Tan, M.-J.; Ye, J.-M.; Turner, N.; Hohnen-Behrens, C.; Ke, C.-Q.; Tang, C.-P.; Chen, T.; Weiss, H.-C.; Gesing, E.-R.; Rowland, A.; et al. Antidiabetic activities of triterpenoids isolated from bitter melon associated with activation of the AMPK pathway. Chem. Biol. $2008,15,263-273$. 
50. Cheng, H.-L.; Huang, H.-K.; Chang, C.-I.; Tsai, C.-P.; Chou, C.-H. A cell-based screening identifies compounds from the stem of Momordica charantia that overcome insulin resistance and activate AMP-activated protein kinase. J. Agric. Food Chem. 2008, 56, 68356843.

51. Chang, C.-I.; Tseng, H.-I.; Liao, Y.-W.; Yen, C.-H.; Chen, T.-M.; Lin, C.-C.; Cheng, H.L. In vivo and in vitro studies to identify the hypoglycaemic constituents of wild variant WB24. Food Chem. 2011, 125, 521-528.

52. Gautam, S.; Pal, S.; Maurya, R.; Srivastava, A.K. Ethanolic extract of stimulates glucose transporter type 4-mediated glucose uptake by the activation of insulin signaling. Planta Med. 2015, 81, 208-214.

53. Cao, H.; Polansky, M.M.; Anderson, R.A. Cinnamon extract and polyphenols affect the expression of tristetraprolin, insulin receptor, and glucose transporter 4 in mouse 3T3-L1 adipocytes. Arch. Biochem. Biophys. 2007, 459, 214-222.

54. Anand, P.; Murali, K.Y.; Tandon, V.; Murthy, P.S.; Chandra, R. Insulinotropic effect of cinnamaldehyde on transcriptional regulation of pyruvate kinase, phosphoenolpyruvate carboxykinase, and GLUT4 translocation in experimental diabetic rats. Chem. Biol. Interact. 2010, 186, 72-81.

55. Lai, D.-M.; Tu, Y.-K.; Liu, I.-M.; Chen, P.-F.; Cheng, J.-T. Mediation of beta-endorphin by ginsenoside $\mathrm{Rh} 2$ to lower plasma glucose in streptozotocin-induced diabetic rats. Planta Med. 2006, 72, 9-13. 
56. Chattopadhyay, R.R. Hypoglycemic effect of Ocimum sanctum leaf extract in normal and streptozotocin diabetic rats. Indian J. Exp. Biol. 1993, 31, 891-893.

57. Shih, C.-C.; Lin, C.-H.; Lin, W.-L. Effects of Momordica charantia on insulin resistance and visceral obesity in mice on high-fat diet. Diabetes Res. Clin. Pract. 2008, 81, 134-143.

58. Asadi-Samani MA, Moradi MT, Mahmoodnia L, et al. Traditional uses of medicinal plants to prevent and treat diabetes; an updated review of ethnobotanical studies in Iran. J Nephropathol. 2017; 6(3):118-25.

59. Mirhoseini M, Saleh N, Momeni A, et al. A study on the association of diabetic dermopathy with nephropathy and retinopathy in patients with type 2 diabetes mellitus. J Nephropathol 2016; 5(4):139-43.

60. Akbari R, Javaniyan M, Fahimi A, et al. Renal function in patients with diabetic foot infection; does antibiotherapy affect it? J Renal Inj Prev 2017; 6(2): 117-21.

61. Tedong L, Dimo T, Dzeufiet P D D, Asongalem A E, Sokeng D S, Callard P, Flejou JF, Kamtchouing P. Antihyperglycemic and renal protective activities of Anacardium occidentale (Anacardiaceae) leaves in streptozotocin induced diabetic rats. Afr J Trad CAM. 2006;3(1):23-35.

62. Schempp C, Schöpf E, Simon J. Plant-induced toxic and allergic dermatitis (phytodermatitis). Hautarzt 2002; 53(2): 93-7. 
63. Boswell-Ruys CL, Ritchie HE, Brown-Woodman PD. Preliminary screening study of reproductive outcomes after exposure to yarrow in the pregnant rat. Birth Defects Res B Dev Reprod Toxicol 2003; 68(5): 416-20.

64. Mahfuz Elmastas a, Lokman Ozturk b, Isa Gokce a, et al. Determination of Antioxidant Activity of Marshmallow Flower (Althaea officinalis L.). Analytical Letters 2004; 37(9): 1859-69.

65. Rouhi-Boroujeni H, Heidarian E, Rouhi-Boroujeni H, et al. Medicinal plants with multiple effects on cardiovascular diseases: A systematic review. Current Pharmaceutical Design 2017, 23, 1-17.

66. Arnault I, Auger J. Seleno-compounds in garlic and onion. J Chromatogr A 4 2006; 1112(1-2): 23-30.

67. Matsga S, Azuma K, Watnabe M, et al. Onion peel tea ameliorates obesity and affects blood parameters in a mouse model of high-fat-diet-induced obesity. Exp Ther Med 2014; 7(2): 379-82.

68. Heidarian E, Jafari-Dehkordi E, Seidkhani-Nahal A. Effect of garlic on liver phosphatidate phosphohydrolase and plasma lipid levels in hyperlipidemic rats. Food Chem Toxicol 2011; 49(5): 1110-4.

69. Durak I, Kavutcu M, Aytac B, et al. Effects of garlic extract consumption on blood lipid and oxidant/antioxidant parameters in humans with high blood cholesterol. J Nutr Biochem 2004; 15(6): 373-7 
70. Prabjone R, Thong-Ngam D, Wisedopas N, et al. Anti-inflammatory effects of Aloe vera on leukocyteendothelium interaction in the gastric microcirculation of Helicobacter pyloriinfected rats. Clin Hemorheol Microcirc 2006; 35(3): 359-66.

71. Im SA, Lee YR, Lee YH, et al. In vivo evidence of the immunomodulatory activity of orally administered Aloe vera gel. Arch Pharm Res 2010; 33(3): 451-6.

72. Rajasekaran S, Sivagnanam K, Subramanian S. Antioxidant effect of Aloe vera gel extract in streptozotocin-induced diabetes in rats. Pharmacol Rep 2005; 57(1): 90-6.

73. Rajasekaran S, Sivagnanam K, Subramanian S. Modulatory effects of Aloe vera leaf gel extract on oxidative stress in rats treated with streptozotocin. J Pharm Pharmacol 2005; 57(2): 241-6.

74. Bolkent S, Akev N, Ozsoy N, et al. Effect of Aloe vera (L.) Burm. fil. leaf gel and pulp extracts on kidney in type-II diabetic rat models. Indian J Exp Biol 2004; 42(1): 48-52.

75. Chithra P, Sajithlal GB, Chandrakasan G. Influence of aloe vera on the healing of dermal wounds in diabetic rats. J Ethnopharmacol 1998, 59(3) 205-201.

76. Budzinski J, Trudeau V, Drouin C, et al. Modulation of human cytochrome P450 3A4 (CYP3A4) and Pglycoprotein (P-gp) in Caco-2 cell monolayers by selected commercialsource milk thistle and goldenseal products. Can J Physiol Pharmacol 2007; 85(9): 966-78.

77. Bahramikia S, Yazdanparast R. Efficacy of different fractions of leaves on serum lipoproteins and serum and liver oxidative status in experimentally induced hypercholesterolaemic rat models. Am J Chin Med 2009; 37(4): 685-99. 
78. Li R, Zhang J, Zhang L, Cui Q, Liu H. Angelica Injection Promotes Peripheral nerve structure and function recovery with increased expressions of nerve growth factor and brain derived neurotrophic factor in diabetic rats. Curr Neurovasc Res 2010; 7(3): 213-22.

79. Watt G.: Periodical Experts: A Dictionary of the Economical Products of India, p. 260, Cosmo Publications, Delhi, 1972.

80. Gupta RK, Kesari AN, Murthy PS, et al. Hypoglycemic and antidiabetic effect of ethanolic extract of leaves of Annona squamosa L. in experimental animals. J Ethnopharmacol 2005; 13; 99(1): 75-81.

81. Adewole SO, Caxton-Martins EA. Morphological changes and hypoglycemic effects of annona muricata Linn (annonaceae) leaf aqueous extract on pancreatic B-cells of streptozotocin-treated diabetic rats. Afr. J Biomed Res 2006; 9: 173-87.

82. Liu ZQ, Li QZ, Qin GJ. Effect of Astragalus injection on platelet function and plasma endothelin in patients with early stage diabetic nephropathy. Zhongguo Zhong Xi Yi Jie He Za Zhi 2001; 21 (4): 274-6.

83. Liu KZ, Li JB, Lu HL, et al. Effects of Astragalus and saponins of Panax notoginseng on MMP-9 in patients with type 2 diabetic macroangiopathy. Zhongguo Zhong Yao Za Zhi 2004; 29 (3): 264-6.

84. Chen W, Li YM, Yu MH. Astragalus polysaccharides: an effective treatment for diabetes prevention in NOD mice. Exp Clin Endocrinol Diabetes 2008; 116 (8): 468-74. 
85. Zhang J, Xie X, Li C, Fu P. Systematic review of the renal protective effect of Astragalus membranaceus (root) on diabetic nephropathy in animal models. J Ethnopharmacol 2009; 126 (2): 189-96.

86. Rouhi-Boroujeni H, Rouhi-Boroujeni HA, Heidarian E, et al. Herbs with antilipid effects and their interactions with statins as a chemical anti- hyperlipidemia group drugs: A systematic review. ARYA Atheroscler 2015; 11(4): 252-8.

87. Mirhosseini M, Baradaran A, Rafieian-Kopaei M. Anethum graveolens and hyperlipidemia: A randomized clinical trial. J Res Med Sci 2014; 19(8): 758-61.

88. Sujatha G, Ranjitha Kumari BD. Effect of phytohormones on micropropagation of Artemisia vulgaris L. Acta Physiologiae Plantarum 2007, 29(3): 189-195.

89. Singh R, Subrata DE, and Belkheir A. Avena sativa (Oat), A Potential Neutraceutical and Therapeutic Agent: An Overview. Critical Reviews in Food Science and Nutrition 2013, $53: 126-144$.

90. Heidarian E, Rafieian-Kopaei M, Khoshdel A, et al. Metabolic effects of berberine on liver phosphatidate phosphohydrolase in rats fed on high lipogenic diet: an additional mechanism for the hypolipidemic effects of berberine. Asian Pacific J Trop Biomed 2014. 31(4): S429-35.

91. Ebrahimi-Mamaghani M, Arefhosseini SR, Golzar M, et al. Longterm effects of processed berberis vulgaris on some metabolic syndrome components. Canadian J Forest Res 2009; 39(11): 2109-18. 
92. Nadkarni KM. Indian Materia Medica, 3rd ed., Popular Book Depot, Mumbai, 1954. pp. 202-207

93. Rao KN, Krishna MB, Srinivas N. Effect of chronic administration of Boerhaavia diff usa Linn. leaf extract on experimental diabetes in rats. Trop J Pharma Res 2004; 3: 305-9.

94. Upaganlawar H, Ghule B. Pharmacological Activities of Boswellia serrata Roxb. - Mini Review. Ethnobotanical Leaflets. 2009, 13: 766-774.

95. Purohit A, Sharma A: Blood glucose lowering potential of Bougainvillea spectabilis leaf extract in streptozotocin induced type-I diabetic albino rats. Indian Drugs 2006; 43: 538.

96. Addae MI, Achenbach H. Terpenoids and flavonoids of Bridelia ferruginea. Phytochemistry 1985; 24(8): 1817-19.

97. Ribaldo PDB, Souza DS, Biswas SK, et al. Green tea (Camellia sinensis) attenuates nephropathy by downregulating nox4 NADPH oxidase in diabetic spontaneously hypertensive rats. J Nutr 2009; 139(1): 96-100.

98. Yamabe N, Kang KS, Hur JM, et al. Matcha, a powdered green tea, ameliorates the progression of renal and hepatic damage in type 2 diabetic OLETF rats. J Med Food 2009; 12(4): 714-21.

99. Babu PV, Sabitha KE, Shyamaladevi CS. Therapeutic effect of green tea extract on oxidative stress in aorta and heart of streptozotocin diabetic rats. Chem Biol Interact 2006; 162(2): 114- 20 . 
100. Mustata GT, Rosca M, Biemel KM, et al. Paradoxical effects of green tea (Camellia sinensis) and antioxidant vitamins in diabetic rats: improved retinopathy and renal mitochondrial defects but deterioration of collagen matrix glycoxidation and crosslinking.Diabetes 2005; 54(2): 517-26.

101. Renno WM, Abdeen S, Alkhalaf M, Asfar S. Effect of green tea on kidney tubules of diabetic rats. Br J Nutr 2008; 100(3) 652-9.

102. Marfo EK, Wallace P, Timpo G, et al. Cholesterol lowering effect of jackbean (Canavalia ensiformis) seed protein. Pharmacology 1990; 21 (5): 753-57.

103. Enyikwola O, Addy EO, Adoga GI. Hypoglycaemic effect of Canavalia ensiformis (Leguminosae) in albino rats. Discov. Innovat 1991; 3(3): 61-63.

104. Asolkar LV, Kakkar KK, Chatre OJ. Glossary of Indian medicinal plants with active principles (Part I) A-K series. Publication and Information Directorate, CSIR, New Delhi 1992: pp. 176.

105. Yoganarasimhan SN. Medical plants of India, 2nd ed., Tamilnadu, International Book Publishers., Print Cyber Media., Bangalore 2000. pp. 109-110,

106. Chandramohan G, Al-Numair KS, Pugalendi KV. Effect of 3-hydroxymethyl xylitol on hepatic and renal functional markers and protein levels in streptozotocin- diabetic rats. Afr J Biochem Res 2009; 3(5): 198-204. 
107. Babu V, Gangadevi T, Subramoniam A. Anti-hyperglycaemic activity of cassia Kleinii leaf extract in glucose fed normal rats and alloxan-induced diabetic rats Indian J Pharmacol $2002 ; 34(6) ;, 409-415$.

108. Abu-Zeyad R, Khan AG, Khoo C. Occurrence of arbuscular mycorrhiza in Castanospermum australe A. Cunn. \& C. Fraser and effects on growth and production of castanospermine. Mycorrhiza 1999, 9: 111-17.

109. Zhang WY, Li Wan Po A. The effectiveness of topically applied capsaicin. A metaanalysis. Eur J Clin Pharmacol 1994, 46(6): 517-22.

110. Forst T, Pohlmann T, Kunt T, et al. The influence of local capsaicin treatment on small nerve fibre function and neurovascular control in symptomatic diabetic neuropathy. Acta Diabetol 2002; 39(1): 1-6.

111. Capsaicin Study Group. Effect of treatment with capsaicin on daily activities of patients with painful diabetic neuropathy. Diabetes Care 1992; 15(2): 159-65.

112. Biesbroeck R, Bril V, Hollander P, et al. A double-blind comparison of topical capsaicin and oral amitriptyline in painful diabetic neuropathy. Adv Ther 1995, 12(2): 11120.

113. Capsaicin Study Group. Treatment of painful diabetic neuropathy with topical capsaicin. A multicenter, double-blind, vehicle-controlled study. Arch Intern Med 1991; 151(11): 2225-9. 
114. Don G. Medicinal plants of the world, Ross I.A. Ed., Humana Press, Totowa, NJ. 1999. pp. 109-118.

115. Abd El-Ghany MA, Nagib RM, Mamdouh SM. Anti-diabetic effect of some herbs and fruit against Streptozotocin induced diabetic rats. Global Veterinaria. 2014, 12(4): 541-49.

116. González-Molina E, Moreno DA, García-Viguera C. Genotype and harvest time influence the phytochemical quality of Fino lemon juice (Citrus limon (L.) Burm. F.) for industrial use. J Agric Food Chem 2008, 56(5), 1669-75.

117. Khan A, Safdar M, Ali Khan MM. Cinnamon improves glucose and lipids of people with type 2 diabetes. Diabetes Care 2003; 26(12): 3215-18.

118. Kim SH, Hyun SH, Choung SY. Antioxidative effects of Cinnamomi cassiae and Rhodiola rosea extracts in liver of diabetic mice. Biofactors 2006; 26(3) 209-19.

119. Mishra A, Bhatti R, Singh A, et al. Ameliorative effect of the cinnamon oil from Cinnamomum zeylanicum upon early stage diabetic nephropathy. Planta Med 2010; 76 (5): 412-7.

120. Jalili J, Askeroglu U, Alleyne B, et al. Herbal products that may contribute to hypertension. Plast Reconstr Surg 2013; 131(1): 168-73.

121. Rasmussen C, Glisson J. Dietary Supplements and Hypertension: Potential Benefits and Precautions. J Clin Hypertension 2012; 14 (7): 467-71. 
122. Cerda JJ, Robbins FL, Burgin CW, Baumgartner TG, et al. The effects of grapefruit pectin on patients at risk for coronary heart disease without altering diet or lifestyle. Clin Cardiol 1988; 11(9): 589-94.

123. Bailey DG, Dresser GK. Interactions between grapefruit juice and cardiovascular drugs. Am J Cardiovasc Drugs 2004; 4(5): 281-97.

124. Prasannakumar G, Sudeesh S, Vijayalakshmi NR, et al. Prasannakumar G, Sudeesh S, Vijayalakshmi NR. Hypoglycemic effect of Coccinia indica: Mechanism of action. Planta Med 1993; 59: 330-2.

125. Grindley PB, Omoruyi FO, Asemota HN, et al. Effect of yam (Dioscorea cayenensis) and dasheen (Colocassia esculenta) extracts on the kidney of streptozotocin-induced diabetic rats. Int J Food Sci Nutr 2001; 52(5): 429-33.

126. Badole S, Patel N, Bodhankar S, et al. Antihyperglycemic activity of aqueous extract of leaves of Cocculus hirsutus (L.) Diels in alloxan-induced diabetic mice. Indian J Pharmacol 2006; 38(1): 49-53.

127. Punitha I.S.R., Rajendran K., Shirwaikar A., et al.: Alcoholic Stem Extract of Coscinium fenestratum Regulates Carbohydrate Metabolism and Improves Antioxidant Status in Streptozotocin-Nicotinamide Induced Diabetic Rats. Evid Based Complement Alternat Med. 2005; 2(3):375-81.

128. Ruel G, Pomerleau S, Couture P, et al. Favourable impact of low-calorie cranberry juice consumption on plasma HDL-cholesterol concentrations in men. . Br J Nutr 2006; 96(2): 357-64. 
129. Rafieian-Kopaei M, Asgary S, Adelnia A, et al. The effects of Cornelian cherry on atherosclerosis and atherogenic factors in hypercholesterolemic rabbits. J Med Plants Res. 2011; 5(13): 2670-6.

130. Wang J, Xiong X and B Feng B. Effect of Crataegus usage in cardiovascular disease prevention: An evidence-based approach. Evidence-Based Complementary and Alternative Medicine 2013; 14: 93-9.

131. Priya S. Phytochemical screening and trace element analysis of Cryptomeria japonica. RRJBT 2014; 4: 17-20.

132. Abdalbasit M, Bertrand M, Bertrand M. Fatty acids, tocopherols,sterols, phenolic profiles and oxidative stability of cucumis melo var. Agrestis oil. J Food Lipids 2008; 15: $56-67$.

133. Fleshman M, Lester G, Riedl K, et al. Carotene and novel apocarotenoid concentrations in orange-fleshed cucumis melo melons: determinations of $\beta$-carotene bioaccessibility and bioavailability. J Agric Food Chem. 2011; 59(9): 4448-54.

134. Abuelgassim O and Showayman AL-showayman. The Effect of Pumpkin (Cucurbita Pepo L) Seeds and L-Arginine Supplementation on Serum Lipid Concentrations in Atherogenic Rats. Afr J Tradit Complement Altern Med 2012; 9(1): 131-7.

135. Valenta o P, Fernandes E, Carvalho F. Antioxidative properties of cardoon (Cynara cardunculus L.) infusion against superoxide radical, hydroxyl radical, and hypochlorous acid. J. Agric. Food Chem. 2002; 50: 4989-99. 
136. Suryanarayana P, Satyanarayana A, Balakrishna N, et al. Effect of turmeric and curcumin on oxidative stress and antioxidant enzymes in streptozotocin-induced diabetic rat. Med Sci Monit 2007; 13(12): BR286-92.

137. Mrudula T, Suryanarayana P, Srinivas PN, et al. Effect of curcumin on hyperglycemiainduced vascular endothelial growth factor expression in streptozotocin-induced diabetic rat retina. Bio-Chem Biophys Res Commun 2007; 361(2): 528-32.

138. Surles Rl, Weng N, Simon PW. Carotenoid Profiles and Consumer Sensory Evaluation of Specialty Carrots (Daucus carota, L.) of Various Colors. J. Agric. Food Chem 2004; 52: $3417-21$.

139. Tavili A, Pouzesh H, Farajolahi A. The effect of different treatments on improving seed germination characteristics in medicinal species of Descurainia sophia and Plantago ovata. Afr. J. Biotechnol 2010; 9(39): 6588-93.

140. Englian, C, Shilling, W, Honghua X, 2005. Analysis ofthe volatile oil from Desmodium styracifolium (Osbeck) Merr. by gas chromatography-mass spectrometry. Guangzhou University of Chinese Medicine.2005; 22: 302-303.

141. Iwu MM, Okunji CO, Akah P, et al. Hypoglycaemic activity of dioscoretine from tubers of Dioscorea dumetorum in normal and alloxan diabetic rabbits. Planta Med. 1990 Jun; 56(3): 264-7.

142. Rachel NU. Control of hyperlipidaemia, hypercholesterolaemia and hyperketonaemia by aqueous extract of Dioscorea dumetorum tuber. Trop J Pharm Res 2003; 2(1): 183- 7 143- Geetha BS, Mathew BC, Augusti K. Hypoglycemic effects of leucodelphinidin 
derivative isolated from Ficus bengalensis (Linn). Indian J Physiol Pharmacol 1994; 38(3): 220-2.

144. Ghosh R, Sharachandra KH, Rita S, et al. Hypoglycemic activity of Ficus hispida (bark) in normal and diabetic albino rats. Indian J Pharmacol 2004; 36: 222-5.

145. Kesavulu MM, Kameswararao B, Apparao C, et al. Effect of omega-3 fatty acids on lipid peroxidation and antioxidant enzyme status in type 2 diabetic patients. Diabetes Metab 2002; 28(1): 20-6.

146. Chiu WC, Hou YC, Yeh CL, et al. Effect of dietary fish oil supplementation on cellular adhesion molecule expression and tissue myeloperoxidase activity in diabetic mice with sepsis. Br J Nutr 2007; 97(4): 685-91.

147. Rizza S, Tesauro M, Cardillo C, et al. Fish oil supplementation improves endothelial function in normoglycemic offspring of patients with type 2 diabetes. Atherosclerosis 2009; 206(2): 569- 74.

148. He CY, Li WD, Guo SX, et al. Effect of polysaccharides from Ganoderma lucidum on streptozotocin-induced diabetic nephropathy in mice. J Asian Nat Prod Res 2006; 8(8): 70511.

149. Meng WL, Wang RJ, Yu J. Clinical observation on treatment of diabetic peripheral neuphropathy by ginkgo leaf extract combined with active vitamin B12. Zhongguo Zhong Xi Yi Jie He Za Zhi 2004; 24(7): 645-6. 
150. Zhu HW, Shi ZF, Chen YY. Effect of extract of ginkgo bilboa leaf on early diabetic nephropathy. Zhongguo Zhong Xi Yi Jie He Za Zhi 2005; 25(10): 889-91.

151. Li XS, Zheng WY, Lou SX, et al. Effect of Ginkgo leaf extract on vascular endothelial function in patients with early stage diabetic nephropathy. Chin J Integr Med 2009; 15(1): 26-9.

152. Lu Q, Yin XX, Wang JY, et al. Effects of Ginkgo biloba on prevention of development of experimental diabetic nephropathy in rats. Acta Pharmacol Sin 2007; 28(6): 818-28.

153. Ramkumar KM, Latha M, Venkateswaran S, et al. Modulatory effect of Gymnema montanum leaf extract on brain antioxidant status and lipid peroxidation in diabetic rats $\mathbf{J}$ Med Food 2004; 7(3): 366-71.

154. Azadbakht L, Atabak S, Esmaillzadeh A. Soy protein intake, cardiorenal indices, and C-reactive protein in type 2 diabetes with nephropathy: a longitudinal randomized clinical trial. Diabetes Care 2008; 31(4): 648-54.

155. Van Wyk BE, Van O, Gericke N. Medical plants of South Africa, 1st ed., Briza Publications, Pretoria 1997. p. 156,

156. S'Bahle MX, John AO. Hypoglycaemic effects of hypoxis hemerocallidea (fisch and C.A. MEY.) corm 'African potato' methanolic extract in rats. Med J Islam Acad Sci 2000; 13(2); 75-78. 
157. McKay DL, Chen CY, Yeum KJ, et al. Chronic and acute effects of walnuts on antioxidant capacity and nutritional status in humans: a randomized, cross-over pilot study. Nutr J 2010; 9(1): 21.

158. Pan A, Demark-Wahnefried W, Ye X, et al. Effects of a flaxseedderived lignan supplement on C-reactive protein, IL-6 and retinolbinding protein 4 in type 2 diabetic patients. Br J Nutr 2009; 101(8): 1145-9.

159. Haliga R, Mocanu V, Paduraru I, et al. Effects of dietary flaxseed supplementation on renal oxidative stress in experimental diabetes. Rev Med Chir Soc Med Nat Iasi 2009; 113(4): 1200-4.

160. Li XM. Protective effect of Lycium barbarum polysaccharides on streptozotocininduced oxidative stress in rats. Int J Biol Macromol 2007; 40(5): 461-5.

161. Teoh SL, Latiff AA, Das S. The effect of topical extract of Momordica charantia (bitter gourd) on wound healing in nondiabetic rats and in rats with diabetes induced by streptozotocin. Clin Exp Dermatol 2009; 34(7): 815-2.

162. Chandra A, Mahdi AA, Singh RK, et al. Effect of Indian herbal hypoglycemic agents on antioxidant capacity and trace elements content in diabetic rats. J Med Food 2008; 11(3): $506-12$.

163. Narayan K, a kareSastry KNV. The hypoglycemic effect of Murra koengii on normal and diabetic dog. Mysore J Agric Sci 1975; 9: 132. 
164. Ford I, Cotter MA, Cameron NE, et al. The effects of treatment with alpha-lipoic acid or evening primrose oil on vascular hemostatic and lipid risk factors, blood flow, and peripheral nerve conduction in the streptozotocin-diabetic rat. Metab Clin Exp 2001; 50(8): 868-75.

165. Hamden K, Allouche N, Damak M, et al. Hypoglycemic and antioxidant effects of phenolic extracts and purified hydroxytyrosol from olive mill waste in vitro and in rats. Chem Biol Interact 2009; 180(3): 421-32.

166. Medeiros FJ, Aguila MB, Mandarim-de-Lacerda CA. Renal cortex remodeling in streptozotocin-induced diabetic spontaneously hypertensive rats treated with olive oil, palm oil and fish oil from Menhaden. Prostaglandins Leukot Essent Fatty Acids 2006; 75(6): 35765.

167. Zhao GH, Shen YS, Ma JB, et al. Protection of polysaccharides-2b from mudan cortex of Paeonia suffruticosa on diabetic cataract in rats. Zhongguo Zhong Yao Za Zhi 2007; 3 (19) 2036-9.

168. John LS, John TA, Lawrence AL, et al. Antidiabetic plants. J Am Coll Nutr 2003; 22, 524.

169. Zhao L, Lan LG, Min XL, et al. Integrated treatment of traditional Chinese medicine and western medicine for early- and intermediate-stage diabetic nephropathy. Nan Fang Yi Ke Da Xue Xue Bao 2007; 27(7): 1052-5. 
170. Ryu JK, Lee T, Kim DJ, et al. Free radical-scavenging activity of Korean red ginseng for erectile dysfunction in noninsulin- dependent diabetes mellitus rats. Urology 2005; 65(3): $611-5$.

171. Cesarone MR, Belcaro G, Rohdewald P, et al. Improvement of diabetic microangiopathy with pycnogenol: A prospective, controlled study. Angiology 2006; 57(4): 431-6.

172. Belcaro G, Cesarone MR, Errichi BM, et al. Diabetic ulcers: microcirculatory improvement and faster healing with pycnogenol. Clin Appl Thromb Hemost 2006; 12(3): $318-23$.

173. Dong W, Shi HB, Ma H, et al. Homoisoflavanones from Polygonatum odoratum rhizomes inhibit advanced glycation end product formation. Arch Pharm Res 2010; 33(5): 669-74

174. McLennan SV, Bonner J, Milne S, et al. The anti-inflammatory agent Propolis improves wound healing in a rodent model of experimental diabetes. Wound Repair Regen 2008; 16(5): 706-13.

175. Lotfy M, Badra G, Burham W, et al. Combined use of honey, bee propolis and myrrh in healing a deep, infected wound in a patient with diabetes mellitus. Br J Biomed Sci 2006; 63(4): 171-3.

176. Bebrevska L, Foubert K, Hermans N, et al. In vivo antioxidative activity of a quantified Pueraria lobata root extract. J Ethnopharmacol 2010; 127(1): 112-7. 
177. Rosenblat M, Hayek T, Aviram M. Anti-oxidative effects of pomegranate juice (PJ) consumption by diabetic patients on serum and on macrophages. Atherosclerosis 2006; 187(2): 363-71.

178. Fenercioglu AK, Saler T, Genc E, Sabuncu H, Altuntas Y. The effects of polyphenolcontaining antioxidants on oxidative stress and lipid peroxidation in Type 2 diabetes mellitus without complications. J Endocrinol Invest 2010; 33 (2): 118-24.

179. Lau TW, Lam FF, Lau KM, et al. Pharmacological investigation on the wound healing effects of Radix Rehmanniae in an animal model of diabetic foot ulcer. J Ethnopharmacol 2009; 123(1): 155-62.

180. Waisundara VY, Huang M, Hsu A, et al. Characterization of the anti-diabetic and antioxidant effects of rehmannia glutinosa in streptozotocin-induced diabetic Wistar rats. Am J Chin Med 2008; 36(6): 1083-4.

181. Takako Y, Li-Qun H, Yasuko M, et al. Effects of rhubarb extract in rats with diabetic nephropathy. Phytother Res 2097, 11(1): 73-5.

182. Vuksan V, Whitham D, Sievenpiper JL, et al. Supplementation of conventional therapy with the novel grain Salba (Salvia hispanica L.) improves major and emerging cardiovascular risk factors in type 2 diabetes: results of a randomized controlled trial. Diabetes Care 2007; 30(11): 2804-10.

183. Yue KK, Lee KW, Chan KK, et al. Danshen prevents the occurrence of oxidative stress in the eye andaorta of diabetic rats without affecting the hyperglycemic state. J Ethnopharmacol 2006; 106(1): 136-41. 
184. Liu G, Guan GJ, Qi TG, et al. Protective effects of Salvia miltiorrhiza on rats with streptozotocin diabetes and its mechanism.Zhong Xi Yi Jie He Xue Bao 2005; 3(6): 459-62.

185. Wu HN, Sun H. Study on clinical therapeutic effect of composite Salvia injection matched with Western medicine in treating diabetic foot. Zhongguo Zhong Xi Yi Jie He Za Zhi 2003; 23(10): 727-9.

186. Vessal G, Akmali M, Najafi P, et al. Silymarin and milk thistle extract may prevent the progression of diabetic nephropathy in streptozotocin-induced diabetic rats. Ren Fail 2010; 32(6): 733-9.

187. Rahman AU, Zaman K. Medicinal plants with hypoglycemic activity. Ethnopharmacal. 1989; 26: 1-55.

188. Teixeira CC, Fuchs FD, Weinert LS, et al. The efficacy of folk medicines in the management of type 2 diabetes mellitus: results of a randomized controlled trial of Syzygium cumini (L.) Skeels. J Clin Pharm Ther. 2006 Feb;31(1):1-5.

189. Nalamolu KR, Nammi S. Antidiabetic and renoprotective effects of the chloroform extract of Terminalia chebula Retz. seeds in streptozotocin-induced diabetic rats. BMC Complement Altern Med. 2006; 7(6): 17.

190. Nagappa AN, Thakurdesai PA, Venkat Rao N, et al. Antidiabetic activity of Terminalia catappa Linn fruits. J Ethnopharmacol 2003; 88(1): 45-50.

191. Purandare H, Supe A. Immunomodulatory role of Tinospora cordifolia as an adjuvant in surgical treatment of diabetic foot ulcers: a prospective randomized controlled study. Indian J Med Sci 2007; 61(6): 347-55. 
192. Bordia A, Verma SK, Srivastava KC. Effect of ginger (Zingiber officinale Rosc.) and fenugreek (Trigonella foenumgraecum L.) on blood lipids, blood sugar and platelet aggregation in patients with coronary artery disease 1997; 56(5): 379-84.

193. Kaviarasan S, Viswanathan P, Anuradha CV. Fenugreek seed (Trigonella foenum graecum) polyphenols inhibit ethanol-induced collagen and lipid accumulation in rat liver. Cell Biol Toxicol 2007; 23(6): 373-83.

194. Matsunaga N, Imai S, Inokuchi Y, et al. Bilberry and its main constituents have neuroprotective effects against retinal neuronal damage in vitro and in vivo. Mol Nutr Food Res 2009; 53(7): 869- 77.

195. Cui XP, Li BY, Gao HQ, et al. Effects of grape seed proanthocyanidin extracts on peripheral nerves in streptozocin-induced diabetic rats. J Nutr Sci Vitaminol (Tokyo) 2008; 54(4): 321-8.

196. Liu YN, Shen XN, Yao GY. Effects of grape seed proanthocyanidins extracts on experimental diabetic nephropathy in rats. Wei Sheng Yan Jiu 2006; 35(6): 703-5.

197. Udayakumar R, Kasthurirengan S, Vasudevan A, et al. Antioxidant effect of dietary supplement Withania somnifera L. reduce blood glucose levels in alloxan-induced diabetic rats. Plant Foods Hum Nutr 2010; 65(2): 91-8.

198. Parihar MS, Chaudhary M, Shetty R, et al. Susceptibility of hippocampus and cerebral cortex to oxidative damage in streptozotocin treated mice: prevention by extracts of Withania somnifera and Aloe vera. J Clin Neurosci 2004; 11(4): 397-402. 
199. Rafieian-Kopaei M, Nasri H. The ameliorative effect of Zingiber officinale in diabetic nephropathy. Iran Red Crescent Me 2014; 16(5) 145-53.

200. Rouhi-Boroujeni H, Gharipour M, Asadi-Samani M, et al.The protective effects of ginger on the development of coronary atherosclerosis: An experimental animal study. Der Pharmacia Lettre 2016; 8(3): 105-9.

200. John LS, John TA, Lawrence AL, et al. Antidiabetic plants. J Am Coll Nutr 2003; 22, 524.

201. Sokeng SD, Rokeya B, Mostafa M, et al. Antihyperglycemic effect of Bridelia ndellensis ethanol extract and fractions in streptozotocin-induced diabetic rats. Afr $\mathrm{J}$ of Tradit Complement and AlternMed. 2005; 2(2), 94-102.202.

202. Nimenibo-Uadia R. Effect of aqueous extract of Canavalia ensiformis seeds on hyperlipidaemia and hyperketonaemia in alloxan-induced diabetic rats. Biokemistri. $2003 ; 15(1): 7-15$.

203. Singh SN, Vats P, Suri S, et al.: Effect of an antidiabetic extract of Catharanthus roseus on enzymic activities in streptozotocin induced diabetic rats. J. Ethnopharmacol. 2001; 76(3), 269-77.

204. Dhanabal S.P, Koata CK, Ramnathan M, et al. The hypoglycemic activity of Coccinia indica Wight \& Arn and its influence on certain biochemical parameters. Indian J. Pharmacol. 2004; 36(4), 249-50. 
205. Kesari AN, Gupta RK, Watal G. Hypoglycemic effects of Murraya koenigii on normal and alloxan-diabetic rabbits. J Ethnopharmacol. 2005; 97(2), 247-51.

206. Ha H, Kim KH. Pathogenesis of diabetic nephropathy: the role of oxidative stress and protein kinase C. Diabetes Res Clin Pract 1999; 45(2): 147-151.

207. Park KS, Kim JH, Kim MS, et al. Effects of insulin and antioxidant on plasma 8hydroxyguanine and tissue 8-hydroxydeoxyguanosine in streptozotocin-induced diabetic rats. Diabetes 2001; 50(12): 2837-41.

208.Vincent AM, Russell JW, Low P, et al. Oxidative stress in the pathogenesis of diabetic neuropathy. Endocr Rev 2004; 25(4): 612-28.111 
Table 1: Medicinal plants with multiple functions in diabetes mellitus

\begin{tabular}{|c|c|c|c|c|c|c|c|c|}
\hline Scientific name & Family & 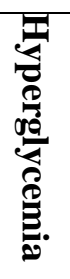 & 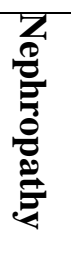 & 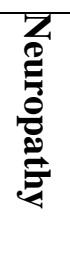 & 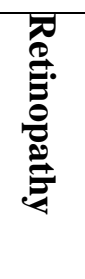 & 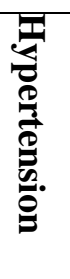 & 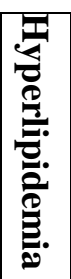 & 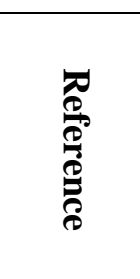 \\
\hline Anacardium occidentale (Leaf) & Anacardiaceae & $\nabla$ & $\nabla$ & & & & & 61 \\
\hline Achillea milefolium (Leaf) & Asteraceae & $\square$ & & & & $\nabla$ & $\nabla$ & 62,63 \\
\hline Althea officinalis (Root) & Malvaceae & $\nabla$ & & & & $\nabla$ & & 64 \\
\hline Allium iranicom (Leaf, Bulb) & Liliaceae & $\square$ & & & & & $\nabla$ & 65 \\
\hline Allium cepa (Leaf, Bulb) & Liliaceae & $\nabla$ & & & & $\nabla$ & $\nabla$ & 66,67 \\
\hline Allium sativum (Leaf, Bulb) & Liliaceae & $\nabla$ & $\nabla$ & & & 田 & $\nabla$ & 68,69 \\
\hline Aloe vera (Leaf) & Liliaceae & $\nabla$ & & & & $\nabla$ & $\nabla$ & $70-75$ \\
\hline Anethum graveolens (Leaf, Seed) & Apiaceae & $\nabla$ & & & & 田 & $\nabla$ & 76,77 \\
\hline Angelica sinensis & Umbelliferae & & & $\square$ & & & & 78 \\
\hline Annona squamosa (Leaf) & Annonaceae & $\nabla$ & & & & $\nabla$ & $\nabla$ & 79,60 \\
\hline Annona muricata (Leaf) & Annonaceae & & $\nabla$ & $\square$ & $\nabla$ & $\nabla$ & & 61 \\
\hline Astragalus membranaceus & Fabaceae & & $\square$ & & & $\nabla$ & & $62-85$ \\
\hline Apium graveolens (Leaf) & Umbellifera & $\nabla$ & & & & 四 & $\nabla$ & 86,87 \\
\hline Artemisia vulgaris (Leaf) & Compositae & $\nabla$ & & & & $\nabla$ & & 88 \\
\hline Arctium loppa (Root) & Compositae & $\nabla$ & & & & 四 & $\nabla$ & 65 \\
\hline Avena sativa (Fruit) & Germinaceae & $\nabla$ & & & & $\nabla$ & $\nabla$ & 89 \\
\hline Berberris vulgaria (Root/Fruit) & Berberidaceae & $\square$ & & & & $\nabla$ & $\nabla$ & 90,91 \\
\hline Boerhaavia diffusa (Leaf) & Nyctaginaceae & $\nabla$ & & & & & & 92,93 \\
\hline Boswellio carteri (Resin) & Burceraceae & $\nabla$ & & & & $\nabla$ & & 94 \\
\hline Bougainvillea spectabilis (Leaf) & Nyctaginaceae & $\nabla$ & & & & & & 95 \\
\hline Bridelia ndellensis (Leaf) & Euphorbiaceae & $\nabla$ & & & & & & 96 \\
\hline Camellia sinensis & Green tea & & $\nabla$ & & $\nabla$ & & & $97-101$ \\
\hline Canavalia ensiformis (seeds) & Leguminosae & $\nabla$ & $\nabla$ & & & $\nabla$ & $\nabla$ & 102,103 \\
\hline Casearia esculenta & Flacourtiaceae & $\nabla$ & $\nabla$ & & & & & 104-106 \\
\hline Cassia kleinii (Leaf) & Caesalpiniaceae & $\nabla$ & & & & & & 107 \\
\hline Castanospermum austral (seeds) & Fabaceae & $\nabla$ & & & & $\nabla$ & & 108 \\
\hline Capsicum frutescens & Solanaceae & & & $\square$ & & & & $109-113$ \\
\hline Catharanthus roseus (Leaf) & Apocyaceae & $\nabla$ & & & & & & 114 \\
\hline Chicorium intybus (Root) & Compositae & $\square$ & & & & $\nabla$ & $\nabla$ & 115 \\
\hline Citrus limon (Fruit) & Rutaceae & $\nabla$ & & & & $\nabla$ & $\nabla$ & 116 \\
\hline Cinnamomum verum (Bark) & Lauraceae & $\nabla$ & & & & 田 & $\nabla$ & 117 \\
\hline Cinnamonum cassia & Lauraceae & $\nabla$ & & & & & & 118 \\
\hline Cinnamomum zeylanicum & Lauraceae & & $\nabla$ & & & & & 119 \\
\hline Citrus aurantium (Fruit) & Rutaceae & $\nabla$ & & & & $\nabla$ & $\nabla$ & 120,121 \\
\hline Citrus paradise (Fruit) & Rutaceae & $\nabla$ & & & & $\nabla$ & $\nabla$ & 122,123 \\
\hline Coccinia indica (Fruit) & Cucurbitaceae & $\nabla$ & & & & & & 124 \\
\hline Colocassia esculenta & Araceae & & $\nabla$ & & & & & 125 \\
\hline Cocculus hirsutus (Leaf) & Menispermaceae & $\nabla$ & 田 & & & & & 126 \\
\hline Coscinium fenestratum (Stem) & Menispermaceae & $\square$ & & & & & & 127 \\
\hline Coriandrum sativom (Fruit) & Umbelliferae & $\nabla$ & & & & & $\nabla$ & 65 \\
\hline Cornus mas (Fruit) & Cornaceae & $\nabla$ & & & & $\nabla$ & $\nabla$ & 128,129 \\
\hline
\end{tabular}




\begin{tabular}{|c|c|c|c|c|c|c|c|c|}
\hline Crataegus microphylla (Leaf/Fruit) & Rosaceae & $\nabla$ & & & & $\nabla$ & $\nabla$ & 130 \\
\hline Cryptomeria japonica (Leaf) & Cupressaceae & $\nabla$ & & & & $\nabla$ & & 131 \\
\hline Cucumis melo (Fruit) & Cucurbitaceae & $\nabla$ & & & & $\nabla$ & $\nabla$ & 132,133 \\
\hline Curcubita pepo (Fruit) & Curcubitaceae & $\square$ & & & & $\square$ & $\square$ & 134 \\
\hline Cynara cardunculus (Flower) & Asteraceae & $\nabla$ & & & & & $\nabla$ & 135 \\
\hline Curcuma longa & Zingiberaceae & $\nabla$ & & & $\nabla$ & & & 136,137 \\
\hline Daucus carota (Fruit) & Umbelliferae & $\nabla$ & & & & $\nabla$ & & 138 \\
\hline Descurainia sophia (seeds) & Brassiacaceae & $\nabla$ & & & & $\nabla$ & & 139 \\
\hline Desmodium styracifolium (Flower) & Fabaceae & $\nabla$ & & & & $\nabla$ & & 140 \\
\hline Dioscorea dumetorum ( Stem) & Dioscoreaceae & $\nabla$ & & & & $\nabla$ & & 141,142 \\
\hline Dioscorea cayenensis & Dioscoreaceae & & $\square$ & & & & & 125 \\
\hline Ficus hispida (Bark) & Moraceae & $\nabla$ & & & & & & 143,144 \\
\hline Fish oil & & & $\square$ & & & $\square$ & & $145-147$ \\
\hline Ganoderma lucidum & Ganodermataceae & & $\nabla$ & & & & & 148 \\
\hline Ginkgo biloba & Ginkgoaceae & & $\nabla$ & & $\nabla$ & $\nabla$ & & $149-152$ \\
\hline Gymnema montanum & Asclepiadaceae & & $\nabla$ & & & & & 153 \\
\hline Glycine max & & & $\nabla$ & & & $\nabla$ & & 154 \\
\hline Hypoxis hemerocallidea Fisch. Mey. & Hypoxidaceae & $\nabla$ & & & & & & 155,156 \\
\hline Juglans regia & Juglandaceae & & & & & & & 157 \\
\hline Linum usitatissimum & Linaceae & $\nabla$ & $\nabla$ & & & & & 158,159 \\
\hline Lycium barbarum & Solanacaea & $\nabla$ & & & & & & 160 \\
\hline Momordica charantia & Cucurbitacaea & & $\nabla$ & $\nabla$ & & & & 161,161 \\
\hline Murraya koenigii Linn & Rutaceae & $\nabla$ & & & & & & 162 \\
\hline Oenothera biennis & Onagraceae & & & $\nabla$ & & & & 163 \\
\hline Olea europaea & Oleaceae & & $\nabla$ & & & & & 164,165 \\
\hline Paeonia suffruticosa & Paeoniaceae & & & & $\nabla$ & & & 166 \\
\hline Panax ginseng (Root) & Araliaceae & $\nabla$ & $\nabla$ & & & & & 167 \\
\hline Panax notoginseng & Araliaceae & & $\nabla$ & & & & & 168,169 \\
\hline Pinus pinaster & Pinaceae & & & & $\nabla$ & & & 170,171 \\
\hline Polygonatum odoratum & Asparagaceae & & $\nabla$ & & & & & 172 \\
\hline Propolis & & & $\nabla$ & & & & & 173,174 \\
\hline Pueraria lobata & Fabaceae & & & & & & & 175,176 \\
\hline Punica granatum & Lythraceae & & & & & $\nabla$ & & 177 \\
\hline Rehmannia glutinosa & Orobanchaceae & & & & & & & 178,179 \\
\hline Rheum officinale & Polygonaceae & & $\nabla$ & & & & & 180 \\
\hline Rhodiola rosea & Crassulaceae & & & & & & & 118 \\
\hline Salvia hispanica & Lamiaceae & & & & & $\nabla$ & & 181 \\
\hline Salvia miltiorrhiza & Lamiaceae & & $\square$ & & & $\square$ & & $182-184$ \\
\hline Silybum marianum & Asteraceae & & $\nabla$ & & & & & 185 \\
\hline Syzyguim cumini (Leaf/Fruit/Seeds/bark/tea) & Myrtaceae & $\nabla$ & $\nabla$ & $\nabla$ & & & & $186-188$ \\
\hline Terminalia chebula (seeds) & Combretaceae & $\nabla$ & $\nabla$ & & & & & 189 \\
\hline Terminalia catappa (Fruit) & Combretaceae & $\nabla$ & $\nabla$ & & & $\nabla$ & & 190 \\
\hline Tinospora cordifolia & Menispermaceae & & & 四 & & & & 191 \\
\hline Trigonella foenum graecum & Fabaceae & & & & $\nabla$ & & & 192,193 \\
\hline Vaccinium myrtillus & Ericaceae & & & & $\nabla$ & & & 194 \\
\hline Vitis vinifera & Vitaceae & $\nabla$ & $\square$ & $\nabla$ & $\nabla$ & & & $\begin{array}{c}185,190,1 \\
96\end{array}$ \\
\hline Withania somnifera & Solanaceae & & & & & & & 197,198 \\
\hline Zingiber officinal & Zingiberaceae & & & 四 & & & & 199,200 \\
\hline
\end{tabular}


Table 2: Mechanism actions of medicinal plants on diabetes and its complications

\begin{tabular}{|c|c|c|c|}
\hline Scientific name & Family & Mechanism & Reference \\
\hline $\begin{array}{l}\text { Anacardium } \\
\text { occidentale Linn. }\end{array}$ & Anacardiaceae & $\begin{array}{l}\text { The antihyperglycemic and nephroprotective effects } \\
\text { are related to reducing diabetes-induced functional } \\
\text { and histological alterations in the kidneys and } \\
\text { reduced accumulation of mucopolysaccharides in the } \\
\text { kidneys. }\end{array}$ & 168 \\
\hline $\begin{array}{l}\text { Annona squamosa } \\
\text { Linn. }\end{array}$ & Annonaceae & $\begin{array}{l}\text { The antidiabetic and hypoglycemic effects of this } \\
\text { plant are associated with increased insulin levels in } \\
\text { the pancreatic islets, increased glucose consumption } \\
\text { in the muscles, and inhibition of hepatic glucose } \\
\text { uptake. }\end{array}$ & 79 \\
\hline $\begin{array}{l}\text { Annona muricata } \\
\text { Linn. }\end{array}$ & Annonaceae & $\begin{array}{l}\text { Reduction of oxidative stress on pancreatic B cells. } \\
\text { The treatment increased the area of insulin } \\
\text { immunoreactive B cells and partially prevented } \\
\text { degeneration of B-cells }\end{array}$ & 81 \\
\hline $\begin{array}{l}\text { Boerhaavia diffusa } \\
\text { Linn. }\end{array}$ & Nyctaginaceae & $\begin{array}{l}\text { The antidiabetic effects of this plant are caused by } \\
\text { lowering blood glucose levels and increasing insulin } \\
\text { sensitivity. }\end{array}$ & 92 \\
\hline $\begin{array}{l}\text { Bougainvillea } \\
\text { spectabilis Linn. }\end{array}$ & Nyctaginaceae & $\begin{array}{l}\text { The antihyperglycemic effects induced by this plant } \\
\text { are due to the increased conversion of glucose to } \\
\text { glycogen in the kidney and increased insulin } \\
\text { sensitivity. }\end{array}$ & 95 \\
\hline $\begin{array}{l}\text { Bridelia ndellensis } \\
\text { Beille. }\end{array}$ & Euphorbiaceae & $\begin{array}{l}\text { Antidiabetic effects of this plant } \\
\text { cells and requires functional B-cell islets }\end{array}$ & 201 \\
\hline $\begin{array}{l}\text { Canavalia } \\
\text { ensiformis DC. }\end{array}$ & Leguminosae & $\begin{array}{l}\text { The antihyperglycemic and antihyperlipidemic } \\
\text { effects of this plant are due to its decreasing blood } \\
\text { glucose and urine levels, as well as its decreasing } \\
\text { triglyceride, ketone bodies, and cholesterol } \\
\text { associated with diabetes mellitus. }\end{array}$ & 202 \\
\hline $\begin{array}{l}\text { Casearia esculenta } \\
\text { Roxb. }\end{array}$ & Flacourtiaceae & $\begin{array}{l}\text { The hypoglycemic effects induced by this plant are } \\
\text { associated with reduced blood glucose levels and } \\
\text { affecting the metabolism of proteins and marker } \\
\text { enzymes. }\end{array}$ & 106 \\
\hline $\begin{array}{l}\text { Cassia kleinii Wight } \\
\text { \& Arn. }\end{array}$ & $\begin{array}{r}\text { Caesalpiniacea } \\
\mathrm{e}\end{array}$ & Reducing blood glucose levels & 107 \\
\hline $\begin{array}{l}\text { Catharanthus } \\
\text { roseus Linn. }\end{array}$ & Apocyaceae & $\begin{array}{l}\text { The mechanism of hypoglycemic action of this plant } \\
\text { is associated with prophylactic activity against } \\
\text { necrotic actions. } \\
\text { Affecting carbohydrate metabolism enzymes. }\end{array}$ & 203 \\
\hline
\end{tabular}




\begin{tabular}{|c|c|c|c|}
\hline & & $\begin{array}{l}\text { Increasing insulin secretion. } \\
\text { Helping prevent damage due to free radical oxygen } \\
\text { and exerting antioxidant effects. } \\
\text { Increasing glucose uptake in tissues }\end{array}$ & \\
\hline $\begin{array}{l}\text { Coccinia indica } \\
\text { Wight \& Arn. }\end{array}$ & Cucurbitaceae & $\begin{array}{l}\text { Exerting B-cell restorative properties against alloxan } \\
\text { induced damage }\end{array}$ & 204 \\
\hline $\begin{array}{l}\text { Cocculus hirsutus } \\
\text { Linn. }\end{array}$ & $\begin{array}{r}\text { Menispermacea } \\
\mathrm{e}\end{array}$ & $\begin{array}{l}\text { Exerting antihyperglycemic effects by reducing } \\
\text { serum glucose levels and increasing glucose } \\
\text { resistance. }\end{array}$ & 126 \\
\hline $\begin{array}{l}\text { Coscinium } \\
\text { fenestratum Colebr. }\end{array}$ & $\begin{array}{r}\text { Menispermacea } \\
\mathrm{e}\end{array}$ & $\begin{array}{l}\text { Regulating the metabolism and improving the } \\
\text { antioxidant effects } \\
\text { Regulating the glucose homeostasis and reducing } \\
\text { gluconeogenesis. } \\
\text { Exerting supportive effect on the antioxidant defense } \\
\text { of the cell }\end{array}$ & 127 \\
\hline $\begin{array}{l}\text { Dioscorea } \\
\text { dumetorum Pax. }\end{array}$ & Dioscoreaceae & $\begin{array}{l}\text { Exerting antihyperlipidemic effects in the body by } \\
\text { controlling hyperketonemia and } \\
\text { hypercholesterolemia. }\end{array}$ & 142 \\
\hline Ficus hispida Linn. & Moraceae & $\begin{array}{l}\text { Reducing fasting blood glucose levels by directly } \\
\text { influencing beta cells }\end{array}$ & 144 \\
\hline $\begin{array}{l}\text { Hypoxis } \\
\text { hemerocallidea } \\
\text { Fisch. Mey. }\end{array}$ & Hypoxidaceae & $\begin{array}{l}\text { The mechanism of the hypoglycemic effect of this } \\
\text { plant has not yet been determined yet. }\end{array}$ & 156 \\
\hline $\begin{array}{l}\text { Murraya koenigii } \\
\text { Linn. }\end{array}$ & Rutaceae & $\begin{array}{l}\text { Exerting hypoglycemic effects by increasing liver } \\
\text { glycogen concentration and affecting carbohydrates } \\
\text { metabolism }\end{array}$ & 205 \\
\hline $\begin{array}{l}\text { Panax ginseng } \\
\text { Linn. }\end{array}$ & Araliaceae & $\begin{array}{l}\text { Exerting hypoglycemic effects by affecting the } \\
\text { metabolism of carbohydrates. }\end{array}$ & 168 \\
\hline $\begin{array}{l}\text { Syzyguim cumini } \\
\text { Linn. }\end{array}$ & Myrtaceae & $\begin{array}{l}\text { Hypoglycemic effects can be exerted via different } \\
\text { mechanisms only in disease conditions and in } \\
\text { diabetic people. }\end{array}$ & 188 \\
\hline $\begin{array}{l}\text { Terminalia chebula } \\
\text { Retz }\end{array}$ & Combretaceae & This plant has renoprotective action. & 189 \\
\hline $\begin{array}{l}\text { Terminalia catappa } \\
\text { Linn. }\end{array}$ & Combretaceae & $\begin{array}{l}\text { Exerting antidiabetic and antihyperglycemic effects } \\
\text { through regeneration of beta cells due to B-carotene } \\
\text { in reducing diabetic complications like glycosylation }\end{array}$ & 190 \\
\hline
\end{tabular}

